\title{
Urethral Suppository Dosage Form
}

National Cancer Institute

\section{Source}

National Cancer Institute. Urethral Suppository Dosage Form. NCI Thesaurus. Code C69053.

A suppository intended for administration within the urethra. 